\title{
5
}

\section{SER MORAL OU NÃO SER HUMANO}

Pergentino S. Pivatto*

SINNTESE - Leitor critico de Husserl e Heidegger, Levinas contesta o primado idealista da consciência intencional e da ontologia sobre a ética. Esta tradição filosófica preserva o privilégio do Eu, na instância da Razão e do Ser. Os postulados éticos que daí derivam resguardam as posiçōes egolátricas, mesmo quando tingidas de universalidade. Pensar uma ética a partir da alteridade é o desafio maior que enfrenta Levinas, abrindo brechas nas concepções de ser e de razão, propondo a relação inter-humana como transcendente-prática que não só sustenta a trama ontológica, mas intervém na própria subjetividade, de forma que o homem ou é moral ou não é humano. PALAVRAS-CHAVE - Ética. Ontologia. Subjetividade. Relação transcendente. Humano.
ABSTRACT - As a critical reader of Husserl and Heidegger, Levinas refutes the idealistic primacy of the intentional relation and ontology over ethics. This philosophical tradition preserves the privilege of the I on the level of reason and being. The ethical postulates of such a position are tainted with "egolatrous" attitudes, even when posited as universal. To think an ethics from the standpoint of alterity is the major challenge for Levinas, as he points to breaches in the conceptions of being and reason, and proposes an inter-human relation, both transcendent and practical, so as to sustain the ontological understanding of reality in subjectivity itself. In a nutshell, human beings are either moral or are not human at all.

KEY WORDS - Ethics. Ontology. Subjectivity. Human.

\section{Introdução}

Levinas afirma ter sido admirador de Heidegger. Narra o fascínio que este exerceu sobre ele, por ocasião do famoso encontro entre Heidegger e Cassirer, realizado em Davos, na Suíça, onde diz ter percebido com nitidez a história do pensamento oscilar e pender para uma nova era que se entreabria sobre o fim do racionalismo kantiano que Cassirer representava. Seus primeiros textos impressos manifestam indubiamente a influência da fenomenologia heideggeriana sobre 0 exercício e o conteúdo filosóficos, embora nos mesmos já se observe espírito agudamente crítico sobre pontos não secundários, conforme nota com precisão Taminiaux, despontem análises distanciadoras que, aos poucos, assumem feição de tomádas de posição bem próprias e originais.

$\mathrm{O}$ confronto torna-se explícito com o artigo de título provocador "A ontologia é fundamental?", publicådo em 1951. Pode-se não reconhecer a importância da questão que o título levanta e ocupar-se com assuntos epocais, patéticos ou lite-

* Professor da Faculdade de Educação e da Faculdade de Filosofia e Ciências Humanas da Pontificia Universidade Católica do Rio Grande do Sul (PUCRS). 
rários. Mas, ao invés, se lhe atribuirmos o valor que nos parece merecer, perceberse-á que tanto Heidegger como Levinas remontam à fonte da filosofia, ao essencial do labor filosófico. Evidentemente, se Levinas se interroga sobre o primado da ontologia é porque discerne nas bases deste privilégio algum esquecimento e mesmo a possibilidade de postular outra tese fundamental: a da ética como filosofia primeira a sustentar não só a ontologia mas a própria filosofia e toda a obra racional que dela procede. Claro está que não basta afirmar o primado da ética como estrutura que subjaz à própria ontologia. Aliás, nem é este o ponto primordialmente visado pelo pensador Levinas. Interessa-lhe, sobretudo, a significância dessa estrutura - a transcendência ética ou o sentido que vai iluminar todo o filosofar e toda a atividade humana. É na relação transcendente-prática que mantém a alteridade como transcendência que Levinas vai descobrir uma trama originária, que receberá o nome de ética, e que embasa a própria estrutura da significância, sobre a qual se constroem as significações, inclusive a da ontologia. Evidentemente, ao se questionar a ontologia, se remexe com todo o arcabouço filosófico, emergindo outras perguntas radicais, como atesta o próprio Levinas: "Que significa a inteligibilidade do inteligível, a significância do sentido, que significa a razão"?

Convém notar também o que Levinas escreveu no impressionante prefácio da obra Totalidade e Infinito: "Talvez seja tempo de reconhecer na hipocrisia, não apenas um mau defeito contingente do homem, mas a divisão profunda de um mundo ligado aos filósofos e aos profetas ao mesmo tempo". Logo adiante, no mesmo prefácio, formula a exigência que conduz à abolição da distinção entre teoria e prática, para que uma e outra possam ser pensadas como dois modos inseparáveis da transcendência. A questão é como superar essa divisão, como jungir razão e ação e como articular o despertar da consciência sem ficar preso no privilégio do ser, suscitando ao mesmo tempo uma relação transcendente e instaura a primazia ética e a mantém como fecundadora de todo filosofar. Em outras palavras: como pensar a ética para que ela seja não apenas um ato derivado da ontologia ou da consciência intencional constituinte, mas se torne a textura mesma da subjetividade humana, de tal forma que o ser humano ou é moral ou não é humano.

\section{Ser e interlocução}

A grande discussão com Heidegger começa na idéia de compreensão do ser. Se todo o homem é ontologia, não se pode favorecer a razão teórica sobre os modos existenciários do ser. O homem todo é compreensão do ser. Mas, nesse caso, escreve Levinas, "compreender torna-se sinônimo de existir". A existência será vista, de novo, como ao longo da tradição, sob o signo teorético da compreensão. Em outras palavras, esta nova filosofia ontológica, qualificada de teorética por estender a compreensão ao existir, respeita o existir de cada um? O ser individual não está sendo subsumido de novo no registro da universalidade própria da compreensão? Não surge aqui um primeiro ato de violência contra o homem? Quem é o culpado por essa violência? Surgirá simplesmente de alguma falta (Schuld) anônima, surgirá de algum esquecimento, surgirá do sistema? Não haverá um lapso na própria "pensamentação" do sistema e, conseqüentemente, na ontologia? 
Como avançar nessa questão em busca de saída? Haverá uma universalidade maior, mais abrangente e mais respeitadora que a da compreensão que engloba tudo no horizonte do ser? A violência e a culpa derivada seriam inerentes ao esforço da razão totalizante, seriam o preço a ser pago pela supremacia do ser?

$\mathrm{O}$ debate vai desencadear-se - espécie de metacrítica, no dizer de Breton em torno da significação da compreensão, da sua universalidade. Levinas estima que Heidegger, apesar de todas as precauções tomadas a respeito das ontologias tradicionais, prolonga a articulação, comum na filosofia ocidental, do particular e do universal: "A inteligência do ente consiste... em percebê-lo no horizonte do ser... Compreender é relacionar-se ao particular, único a existir, pelo conhecimento que é sempre conhecimento do universal" (Entre nós, p. 26). Haveria, portanto, uma redução da afirmação central de que todo o homem é ontologia à compreensão teorética que vê o particular no horizonte do ser universal. Precisamente neste ponto incide a questão levantada por Levinas: não se reduziu o existir ao compreender e, por esse atalho, não se operou a redução do particular ao universal, carreando consigo a perda do concreto, do único a valer que é o ser humano em came e osso? A questão crítica torna-se ética: trata-se da trama que urde o enquadramento ou não do ser único, que é cada homem na sua concretude, na luz do ser universal. O discurso sempre universalizante da compreensão enquadra todo e qualquer particular, por excepcional que seja, na orla do ser. Haveria algo ou alguém que ficaria fora do império do ser? Quem pretenderia tal exceção? Como se justificaria, se fosse viável? Pela simples negação parece inviável, já que o sim e o não pertencem ao âmbito da conjugação do verbo ser. 0 existir vincularia razão e ação que a compreensão separa?

Levinas avança no debate abrindo novas perspectivas que interferem profundamente na concepção de razão, de homem e da relação implicada, pontos estes essenciais mas que não se pode aprofundar aqui. Assim, a relação com um "ente entre outros", ente particular, supera o discurso da compreensão, e por isso se deve dizer que "na nossa relação com outrem, este não nos afeta a partir de um conceito". A relação tem precedência sobre a compreensão, embora esta seja necessária. Esta posterioridade deve ser mantida a todo custo, contra a pretensão da razão de erigir-se como primeira nos atos constituintes. Aqui parece situar-se uma brecha decisiva no discurso perfeitamente liso da razão compreensiva. Como sustentar esta afirmação?

Todo o esforço de compreensão encontra-se de antemão envolvido por um acontecimento de linguagem insuperável (que não é possível controlar): "da compreensão de outrem é inseparável sua invocação” (Entre nós, p. 27). Significa dizer que a cena ocupada pelo desdobramento que vai do sim ao não e do não ao sim o cenário do ser e do nada - não engloba a pressuposição da composição da cena, pois que poderiam significar o sim e o não se não se referissem a alguém que já é invocado, se não estivessem envolvidos numa relação que os sustenta e precede? $\mathrm{O}$ pensamento de Levinas pode ser meditado como ensaio que vara 0 abismo desta brecha, aliás, já intuído e apresentado por Marcel: o fato da invocação deve ele próprio ser referido à epifania do rosto, o outro deve ser descoberto como aquele que desde sempre me precede. 
Mas, nesse caso, pode-se ainda falar em filosofia? A pretensão da razão sempre foi de reduzir o não racional abrindo-o ao racional e, na razão fenomenológica, pelo menos em Husserl, foi de alargar o campo da compreensão para além da esfera dos atos puramente cognitivos. Em princípio, parte-se do pressuposto de que nada se oporia à racionalidade e nada se lhe esconde; e se, porventura, algo se lhe escapa ou a supera não pertenceria mais à ordem humana, nem seria possível uma justificação pelas condições de possibilidade de tal conhecimento. Porém, Levinas intercepta esse movimento omnicompreensivo: detecta seu limite no fato que outrem concretamente me olha, está à minha frente, precede o movimento da compreenssão. A razão é sim onicompreensiva; salvo em relação a outrem. Mas não mostra Heidegger que o ser-com-outrem - o Miteinandersein - repousa sobre a relação ontológica, na qual cada ente particular é compreendido na sua especificidade de ente? Ao que Levinas responde: "na nossa relação com outrem, a questão será deixá-lo ser? A independência de outrem não se realiza na sua função de interpelado? Aquele a quem se fala será previamente compreendido no seu ser?" (Entre nós, p. 27). Nesta altura Levinas interrompe sua caminhada com Heidegger e abre seu próprio caminho. "Outrem não é em primeiro lugar objeto de compreensão e, depois, interlocutor. As duas relações confundem-se. Da compreensão de outrem é inseparável sua invocação" (Éntre Nós, p. 27). É a partir desse patamar e dessa nova direção que se abre a possibilidade de um novo pensar, de uma nova relação inter-humana como ética ou responsabilidade.

Essa novidade fica como que codificada na oposição formal e abstrata da expressão "o Mesmo e o Outro" (cf. $1^{\text {a }}$ seção de Totalidade $e$ infinito), em que se faz um processo de desconstrução das filosofias erigidas sob o cetro do Mesmo, termo sob o qual se formaliza o domínio ontológico. Esse embate confronta as teses básicas do pensamento filosófico, perfazendo um lento e progressivo processo de erosão do primado ontológico e, por outro lado, estabelecendo posições em que alicerça a tese da primazia da ética como subjacente a todo filosofar. Esta tese aparece claramente formulada apenas na página 175 da obra citada: "Ao desvelamento do ser em geral, como base do conhecimento em geral e como sentido do ser, preexiste a relação com o ente que se exprime; ao plano da ontologia, o plano ético".

\section{Significação sem contexto}

Mas não basta afirmar uma tese nova; é preciso estabelecê-la e mostrá-la. Ao fazer isso, não se enredará nas malhas da ontologia, como afirma Derrida, o primeiro comentador e crítico de Levinas? Seria preciso mostrar semelhanças e diferenças, proximidade e distância nas teses em que se confrontam os dois filósofos na posição do fundamento, pesquisa esta que parece não ter sido levada a termo até o momento. $\mathrm{O}$ vínculo que Levinas pretende entre o problema filosófico fundamental que consiste, por um lado, na articulação da transcendência do outro em relação ao ser e da inteligibilidade e, por outro, na manutenção da relação como alteridade (fora das bordas do ser), não é evidente, precisa ser construído e mostrado, do contrário, não haveria ruptura da totalidade inteligível e toda relação vigoraria no horizonte da ontologia onicompreensiva. Por outro lado, sob um ân- 
gulo bem diverso, com fino tato perquiridor e animado pela intenção de compreender, Ricoeur pergunta: como poderá a ética se libertar de sua infatigável confrontação com a ontologia? Que linguagem encontrar para exprimir esta originalidade que desregula o regime do ser e abre a esfera da relação ética? ${ }^{1}$ Será possível subverter a lógica do "logos aglutinador"? Como o outro homem pode ficar fora do círculo da totalidade e ao mesmo tempo significar no "logos apofântico"?

Levinas acena para diferente concepção de inteligibilidade que abre para a possibilidade do pensamento descrever fenomenologicamente a emergência de uma "significação sem contexto" (TI, XII) ou relação transcendente. Significação sem contexto (sem o Da e sem a linguagem ontológica do Dasein) é a definição fenomenológica da "epifania do rosto". Na expressão francesa - "autrui me regarde" - pode-se divisar a mudança de registro: não significa que o eu seja objeto da atenção do outro nem que o outro seja objeto de consideração por parte do eu; mas significa que o outro é imediatamente minha questão, incumbe diretamente a mim, sem levar em consideração espaço e tempo e a linguagem decorrente. Donde me vem essa incumbência? Precede o próprio perguntar da razão recuperadora; tece a própria textura da consciência. É incumbência sem fundamento, não há contexto pelo qual se possa chegar à sua origem; não há horizonte no qual se possa ler sua inscrição e iniciar um processo hermenêutico; e, no entanto, ela urge, significa; hermenêutica alguma me isenta da incumbência que só a mim compete, mesmo que seja superior às minhas forças. Pode-se notar aqui o esforço envidado pelo autor para superar a dicotomia sujeito-objeto que acaba por albergar não só a alteridade no horizonte do ser, sua expressão na verbalidade racional mas a própria relação na sua compreensão intersubjetiva.

Percebe-se logo que isso implica mudança em outro registro essencial, o da subjetividade. Na obra Totalidade e infinito, nota-se o desenvolvimento lento, progressivo e seguro de nova idéia de subjetividade, em contraste sobretudo com a de Husserl, distanciando-se também da de Heidegger. Propõe a "subjetividade como acolhedora de outrem, como hospitalidade"2 (TI, XV). O ponto relevante não consiste no fato de que o outro se me apresenta e assim fica constituído no mesmo horizonte da constituição intencional ou transcendental; nem consiste no fato de que o outro já está comigo, já faz parte do contexto do "da" do Mitdasein e assim me diz respeito porque habitamos o mesmo mundo ao mesmo tempo. Em ambos os casos ficaria anulada completamente a "significação sem contexto" que, Lévinas exige para a relação como alteridade. O ponto arquimédico é que, próximo ou distante, estrangeiro ou companheiro, o Outro põe em questão de tal forma que, quando a razão pergunta pelas condições de possibilidade de tal questionamento, a consciência já se encontra transida por essa relação, abrindo uma brecha e rompendo assim o esquema articulador da inteligibilidade transcendental. 0 questionamento intervém na trama do incessante interessamento do ser por si mesmo que articula toda a existencialidade do Dasein. O outro não é apenas um

1 RICOEUR, P. Autrement. Paris: Puf, 1997, p. 1-2. Este texto será publicado proximamente pela Vozes na versão portuguesa.

2 DERRIDA, J. Adieu à Emmanuel Lévinas. Panis: Galilée, 1997. O segundo texto desta obra contém um estudo sobre o tema da hospitalidade em Totalité et infini de Lévinas. 
mit da sein constituído no mesmo espaço e tempo; o outro extrapola a abrangência do ser. Outro que ser questiona-me a ponto de traumatizar o movimento natural de interessamento constante pelo meu próprio ser, dando azo a um novo movimento - será movimento "contra natura"? - em que o eu amanhece responsável pelo outro. Evidentemente, não se trata de responsabilidade que vem de contexto histórico, social, racial ou algo equivalente, nem de responsabilidade baseada em contratos, em convenções ou em culturas que a promoveriam para reduzir os ímpetos da violência sempre renascente. Trata-se de responsabilidade tão profunda quanto imemorial, subvertedora da ordem instalada pelas significações ontológicas no círculo do ôntico. Ela não se constitui por leis da natureza, nem por contratos sociais, nem está associada a culpas originais e nem é devida a complexos de subordinação ou a traumas históricos.

Outrem é presença "mais íntima a mim que meu próprio íntimo", expressão agostiniana que Levinas adota, conferindo-lhe nova significação. Evidentemente não se trata aqui de uma idéia que se tem do outro ou de um sentimento profundo para com ele, mas do outro interpelante enquanto outro não ontologizado nem situado num da qualquer.

A brecha que se instaura como "significação sem contexto" pode ser aprofundada em várias chaves de leitura. Por exemplo, em relação ao desejo metafísi$\mathrm{Co}$, no qual intervém o tema do outro. À primeira vista, o próprio uso do termo metafísico pode causar estranheza, já que está carregado de significações provenientes da história cultural do Ocidente. Todo esse carreamento de significações produzidas ao longo da história deve ser deixado de lado completamente para se entender o novo sentido que Levinas lhe confere. Por metafísica, Levinas entende uma relação ao outro que se produz no desenrolar da existência terrestre sem culminar na totalidade divina ou humano-histórica, e na qual os sujeitos intervenientes se mantêm absolutos, transcendentes. Fica substituída a inteligência geral dos seres ou ontologia pela metafísica como relação teórico-prática que preserva a alteridade do interlocutor e se mostra crítica em relação a si mesmo e, neste sentido, realiza a essência crítica do saber e do ser e, como tal, se articula como ética fontal.

À primeira vista, a estrutura metafísica do desejo pareceria engajar uma dialética do "familiar" e do "estrangeiro", este considerado como fora do seu hábitat cotidiano (TI, 14), que implicaria o desejo de evasão, de saída do peso e da monotonia do pão de cada dia. No entanto, Levinas atribui uma significação bem diversa à dialética do desejo, diferente da de Heidegger e de outros. Em vez de pensar a filosofia como nostalgia, como desejo de encontrar-se em toda parte como em sua própria casa, que permite articular temas fundamentais do pensamento metafísico tradicional como mundo, finitude e singularidade, Levinas como que inverte o movimento: o desejo metafísico não aspira ao retorno, pois é desejo de um país em que não nascemos (cf. TI, 3). Duas determinações da infinidade própria ao desejo se opõem aqui: uma romântica, própria à Eigentlichkeit, outra ética, que significa o desmedido da infinitude do desejo como sair de si, do seu contexto, do seu mundo, da sua finitude, mas promovendo uma "relação cuja positividade vem do afastamento e da separação" (TI, 4), e que leva a ver a ipseidade-unicidade não 
como Eigentlichkeit, mas como "ex-posição", como "êx-odo", que numa analítica existenciária podem ser descritos como hospitalidade ou como generosidade e bondade, sem ranço de punição ou de culpa.

Dito de outra forma: o desejo metafísico deseja o bem além da totalidade, além do ser; mas não por obra da relação teorética. Esta é capaz de abraçar qualquer distância e, se algo lhe resiste, remete-o ao reino do pré-consciente, do préreflexivo. A relação metafísica só existe na medida em que é realizada como ato próprio do ente concreto - como exposição ou como êxodo - ao contrário do movimento do ser cuja essência procura o que é do seu interesse-natureza. A obra que extrapola a Eigentlichkeit do ser é a bondade do ente concreto que, praticamente, se afasta do seu da e se expõe em des-interessamento, em favor de outrem, mais próximo que o da do Dasein. A relação de responsabilidade que assim se instaura precede toda analítica derivada do ser e seus horizontes, não deriva de alguma falta presente ou passada, própria ou genética, nem da angústia pela própria morte; sua condição de possibilidade é a alteridade proximal que incumbe e prorrompe como desejo metafísico do absolutamente outro, e se verte como generosidade para com o primeiro que aparece, transpondo inclusive a preocupação pela própria morte.

Podemos sintetizar o exposto até aqui: para Levinas, a ontologia, por submeter tudo e todos ao seu denominador, não resguarda a alteridade e a transcendência que a relação metafísica exige. Por isso, a ontologia é vista por Levinas como egologia e violência e a ética que dela deriva e se propõe não passa de ética de interesse e de poder, com justificações racionalizadas.

A obra Totalidade e infinito apresenta-se, por conseguinte, atravessada por uma tese paradoxal: "o fato fundamental da cisão ontológica em Mesmo e em Outro é uma relação não alérgica do Mesmo e do Outro" (TI, 282). Mas os dois intervenientes não são reversiveis. $\mathrm{O}$ eu permanece como ponto de entrada não cambiável, capaz não só de fazer operações transcendentais, mas também de transcender, isto é, de se mover para o plano ético, rompendo a estrutura de interessamento e de poder que a analítica existencial desvela.

\section{Egoísmo e transcendência}

A ontologia é básica. Num primeiro momento, Levinas firma o eu na sua estrutura ontológica, voltado para a sua interioridade-identidade, individuado no seu ser eu-mesmo, incapaz por si mesmo de sair das amarras ontológicas em que arribou. Sufoca nos seus horizontes. A vontade do sujeito é constituída pela necessidade irremissivel da identidade do eu amarrado ao pólo auto-referido, arrimado ao seu ser e, por isso mesmo, forte e viril. A força deste eu consiste no nó indesatável de sua identidade, que perfaz tanto sua dignidade como sua infelicidade. Levinas vê aí o egoísmo original, cuja base é a solidão do gozo e da felicidade, temas estes claramente elaborados nas estupendas descrições da $2^{\mathrm{a}}$ seção de Totalidade e infinito. Porém, o egoísmo não deve ser considerado como um defeito moral ou social do sujeito nem como fonte de culpabilidade, mas como a tensão ainda natural do ser sobre si mesmo, como sua ontologia (Noms propres, p. 104; cf. Autrement qu'être ou Au-delà de l'essence, p. 93). Embora seja sujeito autônomo e separado, contudo "não é absoluto" (TI, 153). 
Porém, é nisso que se deve ver a condição de possibilidade da relação ética como responsabilidade na "significação sem contexto". O autor insiste nessa estrutura, embora não a veja como definitiva nem como a mais profunda. É condição necessária mas não suficiente. Conseqüentemente, a autonomia e a separação do sujeito egoísta são igualmente condição da ruptura da totalidade e da ontologia e, por aí, viabilidade da ética e seu refúgio. Tal ruptura se verifica porque o Mesmo é chamado e questionado pelo Outro, estatutado para além dos parâmetros do ser na relação metafísica. Por esse caminho abre-se a possibilidade da relação social, da transcendência, e só mediante essa possibilidade pode garantir-se uma ética verdadeiramente des-interessada, por onde se instaura uma significação sem contexto para o humano.

O grande esforço especulativo de Levinas consiste, em primeiro lugar, na criação de condições tais para a transcendência que obviem a sua abrangência nos horizontes da imanência ontológica e, em segundo lugar, na inscrição da significância deste movimento-relação como o sentido ético que instaura o humano.

A transcendência implica uma revisão do conceito de consciência intencional, sobretudo da consciência constituinte. A visão intencional do eu e do outro como sujeito e objeto abrangidos na luz panorâmica do ser e da lógica formal igualmente sofre revisão. É preciso, se não sair do idealismo do conhecer, pelo menos relativizá-lo. Quanto a esta limitação, concorda com Heidegger; mas dele diverge frontalmente, no que se refere à significação do humano emergindo como responsabilidade.

No entanto, a pergunta retorna com força: esse eu, o Mesmo, murado em sua identidade e tenso no seu egoísmo, será capaz de transcendência? O desejo de transcender não será nova forma de interessamento, modalidade de explorar as inesgotáveis possibilidades da autenticidade na posição de si mesmo, modalidade de escapar ao poder da morte inexorável, diminuindo ou até anulando o âmbito que Levinas procura abrir como relação transcendente e como significação para o humano, significação que, na prática, vira em responsabilidade?

Só que a responsabilidade, como Levinas a entende, não deriva da natureza nem do ser nem da consciência intencional constituinte nem de cálculos urgidos por necessidades político-sociais. Instaura-se, sim, na relação que se mantém transcendente na prática cotidiana cuja significação é atração do homem que vige na orla do ser para a da responsabilidade pelo humano. É o Rosto, é o Outro em relação concreta e transcendente quem critica o Mesmo, quem lhe faz frente, e que abre, por assim dizer, a dimensão mais profunda da subjetividade do Mesmo, velada pela Jemeinigkeit, a dimensão do desejo ou do Infinito, condição de possibilidade da abertura ou do acolhimento do Outro, por onde se instaura o movimento da transcendência (que não é intencionalidade teórica) que se traduz como relação ética. Racionalidade e ação jungem-se na mesma operação do Mesmo em conversão. Esse movimento de transcendência que converte o interessamento em des-interessamento significa como ética. Portanto, a ética inaugura uma conjuntura em que os termos em relação respeitam sua transcendência na própria relação vigorante. Essa relação é mais profunda que a do ser (TI, 118), relação original irredutivel, mas ao mesmo tempo prática, concreta, no face a face direto e ime- 
diato. A significação dessa relação aponta não para o ser mas para o novo, o humano que, imerso no ser, the sobressai pela glória ética. Glória da ética porque incondicionada e desinteressada.

A transcendência realiza-se, por conseguinte, na concretude da relação social. A relação ética que vai do Mesmo ao Outro torna-se a estrutura fundamental da economia geral do ser ou sua "trama lógica" sob a lógica. Mantém o segredo do Mesmo, sua originalidade (quebra da totalidade e da ontologia), e a transcendência do Outro na diacronia da relação.

Convém insistir num ponto essencial: o Mesmo, ancorado no ser, autônomo, livre, não é capaz por si só (contra os ideais da autonomia da modernidade) de abrir-se à transcendência nem de suscitar relação ética por suas próprias condições de possibilidade. O Mesmo, como foi geralmente interpretado na tradição ocidental, só é capaz, por suas condições, de relações ontológicas, necessariamente imanentes. Toda alteridade, mesmo divina, passa pela objetivação ou pelo ser. Heidegger permanece nesse horizonte; sua analítica existencial, embora critique o fastígio da razão na modernidade, permanece na abrangência do ser e o homem, mesmo pastor do ser, the permanece cativo. Será tão melancólica a vocação e a tarefa do homem para sua humanização e a do seu próximo? É precisamente nesta altura que Levinas produz a interveniência do Outro, como aquele que critica o egoísmo do eu, isto é, a espontaneidade da sua natureza ontológica, a boa consciência da liberdade animal. O Outro interpelante é imprescindível para constituir-se relação e, neste sentido, pode-se dizer que o Outro é condição de possibilidade para o transcender. Sem o outro interpelante, a responsabilidade que uma "boa consciência" pode divisar e até abraçar não passa de apologia pro domo, de conveniência, mesmo que onerosa, ou de legalidade formal gerenciável com base em códigos penais ou em Estados autoritários.

\section{Responsabilidade sem culpa?}

Mas um outro eu, igual ao eu, pode criticar o eu? Sem entrar em detalhes, Levinas diz que o outro é transcendente, ideal, próximo a Deus. Esta afirmação é essencial para se compreender seu pensamento e nela se pode entrever a diferença abismal que medeia a oposição à totalidade, à ontologia e ao "há" anônimo (que prolongam o egoísmo) e a irrupção pro-vocadora do Outro como Rosto, que investe a liberdade espontânea do eu. O Rosto é o Infinito que se exprime, expressão esta que interpela a potência do eu (nas suas diversas formas) e face ao qual pode efetivar-se o movimento de transcendência. Face ao Infinito que se exprime, superando a potência de poder do eu, pode fender-se o bloco da imanência que atenaza o eu na sua identidade e abrir-se-lhe a dimensão do desejo: desejo como nova estrutura - abertura ética - em que o eu tende para o Outro, por entre a trama do ser ontológico que se exaure nas possibilidades de sua "proprieidade". Erige-se uma relação sem totalização, em que o Outro mantém o Mesmo como que estirado para fora de si, a consciência aberta sensível ao Outro. Levinas conclui: "A transcendência como tal é consciência moral. A consciência moral realiza a metafísica, se a métafísica consiste em transcender" (TI, 239). 
Revela-se, assim, a significação metafísica da moralidade. Esta não é uma modalidade qualquer do ser, mas "a orientação inevitável do ser a partir de si para o outro" (TI, 190), a serviço do outro desinteressadamente. Essa orientação é fontal, é mais antiga que todos os movimentos conscientes do eu, mesmo aqueles que, conforme Ser e Tempo, brotam do ser em busca de sua falta de fundamento ou em dívida consigo mesmo por não ter esgotado as possibilidades exploráveis da Jemeinigkeit. Essa dívida consigo mesmo será a fonte da culpa? Culpa que não tem nada a ver com relação inter-humana poderá ser moral? Poderá haver moral num Dasein que só tem a ver com ontologia ou num eu tangido pela consciência intencional constituinte?

A significação fundamental diz que efetivação do humano e relação ética equivalem-se, isto é, a orientação fundamental do ser não consiste na busca da realização de si mesmo, geralmente às custas do outro, mas no fato de ser para 0 outro, com a usura de si mesmo. Ser humano ou ser ético equivale a ser para o outro. Sendo assim, a "significação sem contexto", a relação metafisica inscrevem-se no drama que consiste e se perfaz na passagem do homem visto como ser natural, que se expande e exaure nas possibilidades do seu próprio ser, para 0 homem que se orienta para o outro, alçando-se a humano à medida que abraça o transcender dessa nova orientação. Esse transcender-se verifica-se como movimento de responsabilidade pelo outro. Porém, outro não é aquele que se escolhe; é sempre o primeiro que chega, o próximo, que não depende de minha escolha. Pode-se dizer, com certeza, que esta exigência levinasiana é dramática, pois a liberdade, tão cara à modernidade como mediação ao apogeu da autonomia, é secundarizada em benefício do respeito de cada homem e de sua humanização. A liberdade, geralmente, foi interpretada como absoluta, embora sempre permanecesse o estigma do Absoluto ou do nada nos espasmos da sua condição. Na Jemeinigkeit, a liberdade espraia-se nas infindas possibilidades de busca da autenticidade, tirando como que de uma algibeira mágica seus recursos e sua direção. A questão que se levanta e que permanece mal respondida até hoje pode ser expressa dessa forma: como conjugar liberdade com responsabilidade? Como conjugar culpabilidade e liberdade? A desculpabilização crescente na cultura contemporânea não deriva, pelo menos em parte, da promoção da liberdade entendida como força espontânea expansiva do ser, desatrelando-a de significações e de vínculos trans-psico-subjetivos? A tese de Levinas requer um transcender também neste ponto tão caro e vital aos contemporâneos: a liberdade só se torna humana se receber uma investidura relacional, sem que para tanto seja urgida uma espécie de culpabilização. Neste ponto, Levinas afirma uma tese audaciosa que separa moralidade de culpabilidade. A promoção do homem como passagem de ser natural a ser humano passa pela responsabilidade para com o outro, nisto está sua moralidade. Porém, essa responsabilidade não é objeto de escolha pessoal; é investidura anterior à escolha, o outro investe a liberdade, conferindo-lhe sentido. A liberdade torna-se moral na relação de alteridade. Deve ficar bem claro que isso só é válido na primeira pessoa, como eu. A investidura da responsabilidade não se produz como assunção consciente intencional; é produzida na passividade em que o eu arrima às bordas do ser, pela resposta ao chamado do Infinito, resposta com 
a qual se ergue como ente para o outro, como ser para. A investidura, portanto, não deriva de uma hermenêutica da interioridade, nem de um código de ética ou de uma moral institucional (Estado, Lei, Contrato). O Infinito só pode ser o Bem e do Bem não pode vir senão o bem. A passagem do Infinito deixa um vestígio que a responsabilidade significa, inaugurando o reino da Bondade, a possibilidade da paz e da fraternidade, sem que isto seja entendido como elã altruísta ou derivado de um imperativo categórico à guisa kantiana. Surge a pergunta: não haverá uma violência feita à liberdade humana, que fica alienada desde seu surgimento? Mas, redargúi-se, alguém entende o dom da vida como violência? Mesmo que alguém pense que foi jogado para dentro da existência sem ter sido consultado, irá considerar o seu existir como violência? Assim como a vida em si mesma pode ser considerada como bem, a responsabilidade pode ser apreciada como eleição, como dizer original imemorial do Bem, como vestígio do transcender do Infinito que se passa no Rosto, no próximo que me incumbe. Não se trata de violência mas de eleição, não se trata de faita original mas de responsabilidade marcada pela bondade e pela inocência, por isso precedente toda culpa. Se violência há em subordinar a liberdade à ética, esta a resgata pela bondade como responsabilidade, pela elevação do natural ao humano, pela passagem do espontâneo ao sentido moral, possibilitando a sociedade, a fraternidade e a paz. Nisto está a humanidade do homem, seu privilégio ou eleição: ser para o outro, com responsabilidade infinita (cf. TI, 223). Pelo exposto fica evidenciado que a responsabilidade não é uma qualidade moral, nem um atributo do eu, mas se torna o princípio de individuação do eu humano que transfigura a subjetividade alienável no ser e na totalidade em única, eleita e insubstituível. Percebe-se, assim, como Levinas, ao eliminar toda e qualquer culpa ou dívida originánias, ao secundarizar a liberdade e ao manter a relação na transcendência, distancia-se da visão heideggeriana de culpabilidade e de autenticidade.

\section{Textura moral da subjetividade}

Por outro lado, não deixa de impressionar o fato de Heidegger não ter explorado ou não ter percebido que entre as possibilidades inesgotáveis da Jemeinigkeit poderia estar aquela da relação ética com o outro. Explorou, sim, as possibilidades dentro das condições de possibilidade justificadas. Não teria ele ficado nos limites impostos para visão tradicional da razão ou naqueles formulados por Husserl na quarta e na quinta meditações cartesianas, mesmo criticando-as? Por outro lado, pode-se perguntar se Levinas, ao afirmar a responsabilidade sem limites do eu em relação ao outro, não estará de alguma forma inspirado nas análises do pensamento heideggeriano, tendo procurado explorar caminhos que na visada da autenticidade despontam. Um cotejamento de textos parece promissor face a esta alternativa.

Após a obra Totalidade e infinito, Levinas retoma a questão da subjetividade nucleada como responsabilidade, descreve-a, aprofunda-a sob diversos ângulos a ponto de criar uma nova teoria da subjetividade, surpreendente e provocadora, sob muitos aspectos. Vamos ater-nos apenas a alguns pontos e de forma sumána, nos três textos que atestam essa busca especulativa (AE, HAH, DOVI). 
Levinas retoma a questão da responsabilidade que constitui a subjetividade do sujeito, descobre nela o vestígio de uma "afecção" provocada pelo Infinito, tema este várias vezes analisado e aprofundado. Surge aqui a expressão "traumatismo" para dizer essa experiência irredutível à consciência intencional recuperadora. A "afecção" traumática é an-árquica e dia-crônica, por inscrever-se na passividade da criação ou da eleição. Nessa instância ainda não há um eu que possa assumir a existência. $\mathrm{O}$ autor em foco anda à procura de uma nova forma para descrever a modalidade que precede a entificação de um ser. Usa a partícula "se", não na forma reflexiva mas na forma acusativa. $\mathrm{O}$ eu, na sua modalidade inaugural acusativa, como "se", é pura passividade, pura "afecção" traumática. Ergue-se pelo dizer, pela eleição do Infinito, na passividade acusativa, já suportando o fardo da existência, na severidade da responsabilidade. Nesta altura, responsabilidade não significa um ato livre do sujeito que assume o peso e a graça da existência. Se assim fosse, a subjetividade não seria afetada na passividade acusativa originária do eu como "se", sê-lo-ia apenas na sua modulação. Com essas análises, Levinas quer mostrar que o traumatismo da afecção significa que a subjetividade, na sua passividade acusativa, responde a um chamado, é perpassada pelo outro, é marcada pelo Infinito; significa que o outro está imediatamente no cerne da subjetividade precedendo a própria identidade, já que tudo se produz previamente ao despertar da consciência. Antes de ser, há o chamado para ser. A partícula para denota relação inobjetivável, pois o ser ainda não é. A partícula para transe o ser de tal forma que o ser arribado ergue-se como transcender para. Vai do para ser a ser para. O ser não é a morada do eu. O movimento do para ser a ser para caracteriza o eu. Dito de outro modo: passagem do nada a ser e do ser ao humano moral. A morada do humano é o ser para. O para é o vestígio da relação invocadora e da relação de alteridade como sentido do humano. Agora, a própria subjetividade enquanto tal, transida de relação, é desenrolar da transcendência (cf. EI, 86). Ao despertar, a consciência percebe ter sido "inspirada" e não poder não responder. (cf. DOVI, 124). Nesta nova visão, subjetividade significa relação e transcendência antes de significar identidade e onicompreensão.

A própria análise da sensibilidade, tão belamente desenvolvida em várias passagens da obra Totalidade $e$ infinito, vai tomar novo sentido e novo rumo na obra Autrement qu'être ou Au-delà de l' essence. O para que transe o eu repercute na esfera da sensibilidade. A modalidade imediata do sensível é descrita como exposição ao Outro e como proximidade do rosto. Aqui, a subjetividade, na sua passividade acusativa, é vulnerabilidade, é como que arrancada do gozo (em que vivia despreocupada e soberanamente (cf. TI, $2^{\mathrm{a}}$ seção)), para ser percebida no devotamento ao outro pelo próprio fato da temporalização. O sensível é passivo, a sensibilidade aponta para a passividade do um-para-o-outro. Levinas interpreta este fenômeno como o próprio surgir da significação: um-pelo-outro. A significação decantada na lingüística tem sua condição de possibilidade no traumatismo da relação: um-pelo-outro. A responsabilidade exprime e suporta essa condição de possibilidade da significação. Dai também a idéia de sujeição, de exposição até o ponto de acusação. As marcas do tempo são marcas no corpo como senescência, como envelhecimento, como dor, como suportar. E isto é indesviável, a intencionalidade transcendental nada pode contra o senescer, a razão até pode prever mas 
não desviar essa exposição como sujeição. A subjetividade é, malgré soi, para o outro. Portanto, no mais profundo da subjetividade desponta a significação ética do um-para-o-outro incontornável (cf. AE, 180).

Mediante tais análises, Levinas quer mostrar que a subjetividade não se descreve mais a partir da intencionalidade, da atividade representativa, da objetivação, da liberdade e da vontade. O para repercute igualmente na esfera do tempo. "O sujeito é descrito a partir da passividade do tempo" (AE, 68) que o cerca de todos os lados. Mas, na prática do dia-a-dia, é a singularidade excepcional do rosto que, à guisa do tempo, se torna circum-incessiva com sua significação irrecusável que questiona a intencionalidade do eu e como que o cerca. O rosto extrapola a ordem da presença: "Ele é alteridade; sem medida comum com uma presença ou passado se constituindo em síntese" ( $\mathrm{AE}, 114)$. Ele vem de além, de fora do presente: não há sincronização possivel na exposição da subjetividade como passividade; nela, o tempo passa, enruga, mas não pode ser assumido como presença sincronizante. O rosto, à guisa do Infinito, comanda desde um passado imemorial; a obediência decorrente não é fruto de um ato deliberado no foro da consciência mas surge de uma ordem anterior à escuta, urgindo e significando responsabilidade. A esse apelo, a subjetividade não se pode furtar "sem faltar". Essa visão de falta não deixa de suscitar perplexidade aos olhos modernos e contemporâneos, pelo fato de ser contraída sem ter havido engajamento pessoal direto ou indireto prévio, sem o aval anterior de uma consciência livre. Mostra-se aqui toda a tensão que vara a obra de Levinas: tensão entre ontologia e ética, entre liberdade e responsabilidade. Ele quer significar que a responsabilidade está inscrita no cerne da subjetividade, que ela constitui, por assim dizer, o núcleo mais profundo da própria identidade, ela é o vestígio da para que transe o seu ser.

Pode-se dizer, pois, que há uma heteronomia que marca a metafísica e constitutivamente a subjetividade: heteronomia (ao inverso de Kant) que não é alienação mas libertação do homem. Não é alienação, porque a eleição vem do Bem e o Bem precede a liberdade, conferindo-lhe sentido. A subjetividade sofre a eleição do Bem, sofre-a na sua carne, significando a exposição-sujeição radical a outrem. Eleição que precede uma possivel assunção pela liberdade, e por vir do Bem, a violência que poderia haver no fato da não-liberdade é resgatada pela significância de um sentido melhor que o da perseverança no ser ou da expansão do ser, o sentido melhor do ser-para que se traduz como desinteressamento de si em favor do outro, até a responsabilidade como refém, até a substituição um-pelo-outro. Óbvio é dizer que estamos longe dos ideais da modernidade expressos na autonomia e na emancipação como instâncias de humanização. Um-pelo-outro quebra a auto-suficiência e o individualismo e propõe a construção de uma sociedade a ser humanizada pela fraternidade.

Assim, a moralidade, melhor dito, a responsabilidade pelo outro que expõe ao acusativo (passividade) torna-se a estrutura do humano, para além e mais profundamente que a individuação do eu em mim. É este, sem dúvida, o sentido maior da obra Autrement qu'être ou Au-delà de l'essence: "cada indivíduo é virtualmente um eleito, chamado a sair, por sua vez - ou sem esperar a sua vez - do conceito do Eu, de sua extensão no povo, chamado a responder de responsabilidade: eu, isto é, eis-me aqui para os outros" (AE, 232-233). 
Com essas palavras, Levinas anuncia uma vocação à moralidade, à responsabilidade que constitui a característica fundamental de toda pessoa humana. É vocação universal, mas o estatuto dessa universalidade não poderá mais ser ontológico. Não cabe nos ditos apofânticos do desvelamento do ser. Ergue-se e sustenta-se como homem, cujo viver é perpassado pelo dinamismo do ser para o próximo. No fundo do ser, não está o cuidado de si a prevalecer, mas a exposição como significância do um-para-outro. A unicidade não consiste na autonomia mas em ser para, invertendo, de alguma forma, o movimento centrípeto em centrífugo. A angústia pela morte própria é substituída pela angústia pela morte do outro homem. Vislumbra-se, assim, abertura para o futuro, para a vida, para a riqueza do pluralismo e da diversidade. Nesta nova visão de subjetividade como responsabilidade resplandece a glória que a moral esparze. A textura ética da subjetividade alberga toda questão (a questão é em si mesma testemunho da inscrição moral na subjetividade), sustenta todas as construções ontológico-racionais e anima a busca infindável do sentido do humano ao longo da história.

\section{Conclusão}

Que pensar dessa proposta ética que estrutura a subjetividade como um-pelooutro, como sujeição até a substituição sem lapso de tempo para si e cuja individuação se faz não pela autonomia do eu mas pela responsabilidade crescente e cujo agir é bondade a ponto de quebrar a espontaneidade da essência que se expande em ser para produzir o desinteressamento em favor de outrem, o primeiro a chegar?

Não haverá peso insuportável de culpa não contraída pelo sujeito que deve carregar e cuja extensão e profundidade não cessa de crescer? Haverá como de se libertar desse fardo? Philippe Nemmo, no livro L'excès du mal, mostra uma brecha para a transcendência no próprio excesso do mal. A qüididade do mal consiste no seu próprio excesso injustificável. Por causa do mal, mais ainda por ser excessivo, o ser não encontra repouso. $O$ fato de não encontrar repouso, de não encontrar 0 "da" em que o sujeito possa compor-se, essa modalidade do mal faz com que se arrebentem os próprios limites da imanência e aponte para a transcendência. A partícula ex da palavra excesso abre e aponta para o "trans" do ser; a condição insuportável do mal aponta para a incondição; o ex significa o como que abre para a transcendência, para a excendência. Não se trata de idéia, de atitude piedosa, mas da intencionalidade ligada à própria modalidade do mal na forma da dor que dilacera o ser expondo-o à incondição.

Aqui a pergunta fundamental não é mais ser ou não ser ou porque há algo em vez de nada. A questão incontornável é: por que há mal em vez de bem? (p. 155). Por esse viés, o autor opera uma redução do ontológico, do ser onicompreensivo. A famosa diferença ontológica é precedida pela diferença do bem e do mal. É nessa diferença que se origina o sentido. Tem sentido o que diz respeito à alternativa entre o bem e o mal extremo. Tem significância um movimento em que convergem em sinergia razão e ação. 
Para Levinas, o mal é ser. O mal desenrola-se à guisa do ser que se expande e procura perseverar no ser. A irresponșabilidade (falta, culpa) está em seguir o jogo do ser, seja dito como cuidado (Fürsorge) para com o ser próprio em sua propriedade.

Se o ser é mal, que se pode fazer ou esperar senão uma justificação? E como se dará essa justificação? Não poderá consistir num movimento teorético, numa justificação devota ou altruista, mas num movimento contre-nature, na descoberta da eleição pelo como da passividade, pelo como do excesso do mal, expresso na partícula para. O Bem que chama deixa um vestígio-enigma na passividadesubjetividade que embaralha as certezas da consciência onicompreensiva, provoca a má consciência, despertando-a e abrindo-a como responsabilidade, na transcendência, na orla da bondade. Significa dizer que a própria subjetividade está tecida de relação que a perpassa e secundariza a identidade. Assim como o Bem suscita o ente e se contrai, retirando-se ao passado, no "quase nada", a subjetividade ergue-se passivamente, modalidade de contração que plasma nova modalidade de ser como exposição ao próximo e instaura o reino da ética a sustentar possivelmente a própria ontologia. Nessa nova visão, as próprias categorias de falta e de culpa, implicadas na moral, precisam ser repensadas a partir da subjetividade transitiva. Enfim, o próprio sentido do humano precisa ser revisitado. A partir desta concepção levinasiana pode-se afirmar: ou o ser humano é moral ou não é humano.

\section{Referências bibliográficas}

CIARAMELLI, F. L'enigma del bene e l'origine del senso. Apud FANIZZA, F., FISTETTI, F., PONZIO, A. Lévinas vivant. Riflessioni sul pensiero di Emmanuel Lévinas. Modugno (Bari): Edizioni dal Sud, 1998.

DERRIDA, J. L'Ecriture et la différence. Paris: Seuil, 1967.

- Adieu à Emmanuel Lévinas. Paris: Galilée, 1997.

LEVINAS, E. Totalité et infini. La Haye: M. Nijhoff, 1971. (sigla: TI)

—_. Autrement qu'être ou au-delà de l'essence. La Haye: M. Nijhoff, 1974. (sigla: AE)

— De Dieu qui vient à l'idée. Paris: J. Vrin, 1986. (sigla: DOVI)

- Humanismo do outro homem. Petrópolis: Vozes, 1993. (sigla: HAH)

- Entre Nós: ensaios sobre a alteridade. Petrópolis: Vozes, 1997. (sigla: EN)

NEMMO, Ph. L'excès du mal. Paris: 1978.

TAMINIAUX, J. La première réplique à l'ontologie fondamentale. Apud CHALIER, C., ABENSOUR, M. Emmanuel Lévinas. Paris: Éd. De l'Herne, 1991. 